\title{
Avestan Architecture: A Descriptive Etymological Lexicon
}

\author{
Mahsa HASHEMI ${ }^{1}$, *Hossein NAJARI ${ }^{2}$ \\ ${ }^{1}$ M.A. in Ancient Culture \& Languages, Faculty of Humanities, Shiraz University, Shiraz-IRAN \\ ${ }^{2}$ Hossein NAJARI, Ph.D. in Ancient Culture \& Languages, Assistant Professor in Shiraz University, \\ Shiraz-IRAN \\ E-mail address: hashemi.mahsaa@gmail.com, najari@shirazu.ac.ir
}

\begin{abstract}
Keywords: Avesta, Architecture, Lexicon, Etymology, Iranian studies, Archeology
\end{abstract}
\begin{abstract}
The Avesta could be considered as the most important masterpiece of ancient literature of Iran and its older parts as the oldest belletristic exploits. The importance of Avesta is firstly in its religious value and its sanctity and secondly in the picture it draws for us of ancient Iran. On the other hand, architecture is the greatest aspect of art and a very old one. Not many people have analyzed or interpreted the ancient Iranian texts in the context of architecture. In this research, the focus was on viewing the ancient Architecture of Iran through the Avesta, which was definitely used for religious purposes at that time. There is no doubt that nowadays, centuries after the era of Avesta, there is a huge difference between our modern architecture and the Avestan architecture. The main goal of this research was making a descriptive and etymological lexicon on Avestan architecture. Therefore, firstly every single vocabulary was studied etymologically, discussed literary and also given one example of the use of it in the Avesta. Finally, the authors have reached the conclusion that the Ahuramazda versus Ahriman fight can even be traced in the ancient architecture of Iran and its architectural descriptions, which can be studied more in the future.
\end{abstract}

\section{INTRODUCTION}

Art is one of the most shining and ancient examples of Iranian identity, the evidence of which has existed since 5000 years B.C. Thus Zarei quotes from Andres Godard: "The greatest Iranian art by all means is architecture; this superiority is not only seen in Achaemenid, Parthian and Sassanid architecture, but also in Islamic architecture." (Zarei: 51-52)

Iranian architecture over time has been the illustrator of the ideologies and lifestyles of the people of this land. Customs and traditions, religious rituals, morals, ethics, thoughts and beliefs of generations as well as nature, climate and history, all have been reflected in Iranian architecture; Therefore, an intimate understanding of the ancient architecture of Persia will give you an insight into the ancient Iranians.

Logically and traditionally, the first step in recognition of ancient Iranian architecture or, in other words, the roots of Iranian architecture is to analyze the remaining buildings. But only a few such monuments are left and most of them are nothing more than ruins. The second source to find the roots of Iranian architecture, which has often been neglected by researchers, is to refer to remnants of written scripts which remain from that era in literature, history, theology etc. Generally these archaic documents, which are mostly religious, contain no obvious hints about architecture, but one can still conjure up a picture, albeit vaguely, of ancient Iranian architecture with the help of such texts.

A noticeable aspect of ancient Iranian architecture is its close religious connections. This architecture, certainly, whether in religious buildings or in other buildings has always been inspired by the religious beliefs of the era it belongs to.

Thus Zarei quotes from Pope: "There are various kinds of buildings in Iranian architecture, from peasant cottages, coffee houses and pavilions to the most gorgeous and eye-catching buildings the world has ever seen. Anyhow, Iranian architecture is religious before we can attribute anything else to it. The beginning of it has a magical benedictional characteristic and the guide and creator 
of it is the cosmic symbolism under whose radiance, mankind is tied to heavenly powers and gets accustomed to it." (Zarei: 51-52)

Hence, in order to benefit from ancient texts to achieve an image of the ancient architecture of Persia, one will need to refer to Avesta, which is the most venerable text from ancient times.

Avesta is the religious book of Zoroastrians and one of the most significant epochal texts from ancient Persia. Apart from the book Avesta and some documents related to it, there is no other script in the Avestan language which emphasizes the importance of this book notwithstanding its religious influence. Avesta, an ancient Persian language had been quoted from generation to another for centuries, until it was finally collated and written down at the time of the Sassanids relying on the knowledge of the Zoroastrian clergy and using a new script which was invented based on Pahlavi script (middle Persian). The Sassanid Avesta contained 21 books (Nask) which was yet more concise than the ancient Avesta and now the existing Avesta is about one fourth of the Sassanid Avesta and includes 5 books: 1) Yasna (worship), 2) Yashts (worship), 3) Visparad (all the lords), 4) Vandidad ( the laws of separation from demons) and 5) The little Avesta. In addition to that, Neyrangistan, Hirbodistan, Hadokht Nask and some other scattered documents are considered as Avestan sources. (Amoozegar: 7-8) Apart from the special religious importance of Avesta, it can also be considered as one of the main sources of Iranian identity in its own time, and as a full length mirror of that golden age.

No-one has ever analyzed and interpreted the ancient Persian texts, Avesta in particular, in the context of architecture and art. It can be claimed that ancient Persian architecture is more in the service of religion than anything else and the proof is how terrestrial and heavenly architecture is reflected in Avesta. Avestan architecture can be divided into two categories: 1-verbal 2- descriptive.

\section{Verbal:}

This first division includes the vocabulary which is placed in the architectural domain directly or indirectly, without picturing a certain building or space. The advantage of recognition and perusal of such vocabulary is in getting acquainted to the architectural terms of an epoch which existed centuries before us. Knowing the etymology of most of these words is helpful in finding out the probable differences between the definition of one certain word and its application in two different eras; For example, when it talks about "kata-" and we see its new Persian equivalent "kadeh", if we compare the usage of it in Avesta and what it refers to today, we will see that in the new Persian language this word only means "house" but in Avesta, in addition to the first meaning, it has a second meaning too. In other words, this word has a general meaning which is "house" and also a special meaning. As used in Vandidad, "kata-"actually means "Dakhma" or a temporal place for protecting the corpse during the winter. Therefore, studying this word leads us to a structure which existed in ancient times but no longer today.

\section{Descriptive:}

Only a few buildings were described in Avesta and in most cases Avesta didn't go further than giving a verbal hint. But in a few special cases they are described. The noticeable point about this Avestan description is its religious aspect. In other words, Avesta talks about people's housing all the time but only described the buildings and spaces that have religious importance, but when it comes to terrestrial and tangible buildings and spaces, then it has no description or explanation but their name. This religious importance is not only about divine spaces but also about devilish ones.

The buildings described in Avesta could be divided into two categories of general buildings and special buildings. The general buildings which are described in Avesta are: 1) crypts 2) devils' territories 3) house of believers (Mazadaysnas). The explanations about these spaces are mostly found in Vandidad.

But the second category of descriptive architecture refers to more specific buildings, the common characteristics of which are their supernaturalness. The only particular buildings that were described in Avesta are: 
The palace of Mithra (Mehr) (Mehr Yasht: 44, 50, 51), The palace of Soroush which is on the top of the Alborz mountains with 1000 columns, The Palace of Anahita (Anahid) (Aban Yasht: 101102), which has 1000 columns and 1000 pillars and is located on the shore of a lake, and also the Castle of Jamshid (var-i-Jamkard) (Vandidad: Frgd. 2) which could be considered as an archaic utopia. Beside these divine buildings, there are some references to Afrasyab's underground haven which is a devilish place. The significant matter is the difference between the ways of describing divine and devilish spaces in Avesta. Devilish spaces are described as horrifying and dark places and the divine spaces are extensive, radiant and full of columns and windows.

\subsection{REVIEW OF LITERATURE}

Godard (1936) published his vast researches and findings in Iranian architecture in format of some annual booklets in French which were later gathered in a book in 4 volumes and translated to Persian 50 years later. He also published another book about the Iranian arches in (1990). Pirniya (1990) was innovative with studying the Iranian architecture, from the beginning to Qajarieh, to classify it into 6 categories that present 6 styles of Iranian architecture, two of which are preIslamic. Consequently, Memarian (2004) published an improved version of Pirniya's. Zarei (2000) had a quick look at the history of world's architecture and the Iranian architecture in particular.

There are also some researches, in which, architectural buildings are analyzed by the help of texts and architectural implications inside them. Bahar (1983) published a collection of his articles including an article on Persepolis in which he referred to Avesta several times. Nikoobakht and Gandomani (2006) wrote an essay on mythical buildings and the secret of their eternity in which they studied the comparative mythical architecture of Iran as well as bringing up why the mythical architecture is formed at all. Arzhmand (2008), in an article, looked for the roots of Iranian architecture and its first architects in mythical texts and Shahnameh and Avesta in particular. Jafari Dehaghi (2011) peruses the conception of utopia in Ferdowsi's Shahnameh and compares it with Avestan and Pahlavi utopias. This article is one of very few researches done to study architectural concepts in myths.

\subsection{THE LEXICON OF THE AVESTAN ARCHITECTURE}

In this research, an etymological-descriptive lexicon was collected from Avestan vocabularies which are related to architecture and this lexicon is collocated by the English Alphabet. The method which is applied for classification of those vocabularies is classification based on the definition of words and how they are related to Architecture. And all the combination of vocabularies which were studied in this research can be placed in these five categories:

1) Architectural spaces: road, stable, castle...

2) Elements and details of a building: door, wall, window, beam, column ...

3) Building materials: stone, clay, metals

4) Colors: In Avesta colors are not used for describing a building but they certainly have been connected to architecture, considering how colors are used in remained ancient buildings in Choghazanbil, Bishapoor, Susa, etc.

5) Verbs: some verbs like to habit, to destroy, to build etc which are directly or indirectly related to architecture are put in this category.

\section{ARCHITECTURAL WORD-LIST}

ąi $\vartheta i i \bar{a}$ - : sb. fem. "post".

Skt. ătā- (Bartholomae: 359); there is no evidence of this word in MP.

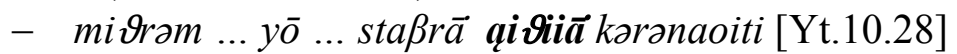

- Miýra... who makes strong the gate-posts (Gershevitch: 87). 
asman-: sb. mas. "Stone"

Av. Asan-, ašn-; Skt. asn, asan-, asman- (Bartholomae: 207); MP. sang [KYPA], ${ }^{2} \operatorname{sag}^{2}\left[\mathrm{sk}^{1}\right.$ ] (Mackenzie: 132-133); MPT. sygyn[segēn] (Boyce: 135); NP. (Nyberg: 162).

- asānaēšuua ... vič̌ič̃ēěšua ... tūtuxšuua... [V.9.11]

- Thou shalt place stones as steps to the holes; or potsherds, or stumps, or clods, or any hard matter (Darmesteter: 122).

aspō.stāna-: sb. mas. "Shed, stable, fold"

AV. aspa-"horse" +stāna- "place" (Reichelt: 227);

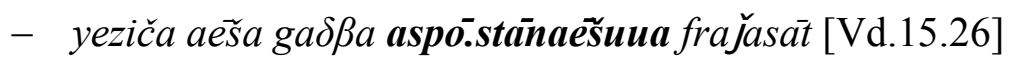

- If a bitch be near her time and be lying in a horse-stall ... (Darmesteter: 177)

asta- : sb. ntr. "house, home"

Skt. ásta- (Bartholomae: 212); MP. pahast (pah+ast) [p'hst ${ }^{1}$ "stable" (Mackenzie: 118).

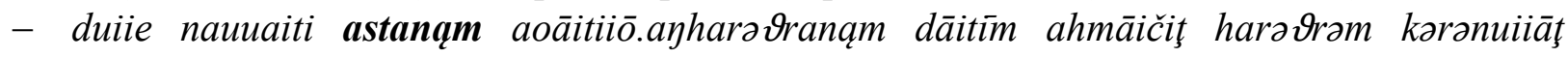
[Vd.14.17]

- He shall put into repair twice nine stables that are out of repair (Darmesteter: 171).

aiiah-: sb. ntr. "metal, iron, iron caldron".

Skt.áyas- (Bartholomae: 159); Ltn. aes (Hasandoost: 1126); MP. āhan, āhen['h(y)n, 's(y)n] (Mackenzie: 35); MPT.' 'hwn [āhun], Prth.' 'swn [āsun] (Boyce: 29); Paz. Āhin ,NP. āhan(Nyberg: 32).

- asmanəm ... yō hištaite ... aiiayhō kəhrpa xvaēnahe [Yt. 13.2]

- yonder heaven above, shining and clear, which is all around this earth, as it were like a bird (all around) an egg, which abides, spiritually established, firmly fixed, with distant limits, with the appearance of a bright crystal (glowing metal) glimmering over the thirds (Malandra: 111).

aiiana- : sb. ntr. "path, road".

Another form for this word in Av. isfraiiana- and the root is ay- "to go" (Bartholomae: 989); Skt. áyana- , pră-yana- (Bartholomae: 157); MP. rāh[1's](Mackenzie: 128).

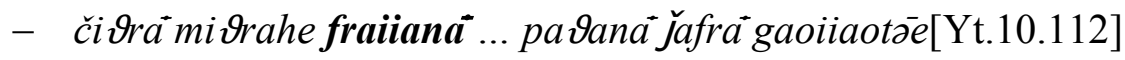

- The clans dear to Mithra - when he visits their country-he treats as those who treat well (Gershevitch: 129).

$\boldsymbol{a} \boldsymbol{\beta} \boldsymbol{\beta} a n-$ : sb. mas. "path, road".

Another form for this word in Av. isadvan-(n.) - and the root is ay- "to go" (Bartholomae: 989);

Skt. ádhvan- (Bartholomae: 989); MP. rāh [1's] (Mackenzie: 128).

- kasnāxuuāng stràmča dā̧ aduuānəm [Y.44.3]

- Who assigned the course of the sun and of the stars (its proper place)? (Humbach: 157).

$\check{\boldsymbol{c}} \overline{\boldsymbol{a}} \boldsymbol{t}-\mathrm{s}$ sb. fem. "well".

Root in Av. Kan-, Derivation: čātaya- (Bartholomae: 583); MP. čāh[c'h](Mackenzie: 56); MPT., Prth. c'h [čāh]; Sog. c't; Chrs. c'h,c't (Hasandoost: 596); NP. čāh (Nyberg: 52).

maè̃e vā čāiti vā [Vd.13.38]

[If the dog] fall into a hole, or a well... (Darmesteter: 160)

daez-/diz-: v. "to build".

Av. Present stem: diz-, daēzaiia- (Kellens: 14); derivations: pairi.daēz- "to build", uz.daēz- "to build" (Cheung: 52). 
Skt. dégdhi- , dihạ́nti- g digdháh- (Bartholomae: 673); IE.*dhei_h- (Pokorny: 244); Mp. inf: dēsïdan, present stem: dēs- (Mackenzie: 64); MPT. Inf: dištan, present stem: dys-[dēs] (Boyce: 65); Khot. däs- , Sog. dys- (Cheung: 52).

- yōaètam uz.daēzam uzdiš̌ta [Vd.15.36]

- He who erected the wall or who holds it ... (Darmesteter: 178)

daiman-: sb. fem. "home, house"./domāna-

OI. dmāna > māna- (Mansoori: 239); Skt. mánah- ‘dámah- (Mayrhofer: 309); IE. men "to stay" (Pokorny: 2070); OP. man (Kent: 202); MP. mān [m'n] (Mackenzie: 103); Prth. m'n[mān] (Boyce : 93); Sogd. myn ’mnty- (mēnāmandē) (Gharib: 225); Paz. man, NP. Mān (Nyberg: 124).

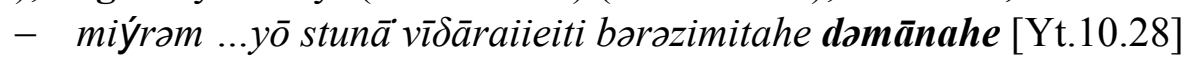

- Miýra... who arranges the columns of the high-pillared house (Gershevitch: 87).

dišta-: participle as sb. fem. "castle".

Av.diz- "to build" - (Bartholomae: 748); Skt. dehí- (Mayrhofer: 749); IE. *dheighā-(Pokorny: 655); OP. didā- "wall" (Kent: 191); MP. diz (Mackenzie: 64); MPT. dyz [diz] (Boyce: 39); Sogd. dizā

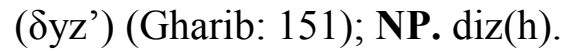

- yōaètam uz.daēzam uzdiš̌ta [Vd.15.36]

- He who erected the wall or who holds it ... (Darmesteter: 178)

duuar-: sb. fem. "door".

Root in Av. dvar- (Bartholomae: 765); Skt. dvar-/durah-/dvarau- (Bartholomae: 378);

OP. duvara- (Kent: 192); MP. dar [BBA] (Mackenzie: 61); MPT. dr[dar] (Boyce: 59);Prth. br[bar] (Boyce: 49); Paz., NP. Dar (Nyberg: 111).

- apiča təm varəm marəza dvarəm raočanəm xuиāraoxšnəm antarə.naēmāț [Vd.2. 38]

- And he goaded them wih the golden pick and stroked the enclosure from behind (to make) a door admitting light, self-shining from within (Skjaervo: 125)

fra.sčimbana-: sb. ntr. "beam".

Av. fra-skəmba- (Reichelt: 246); fra+skamb- (Bartholomae: 1002); Skt. Skámbhana- , skambhá(Bartholomae: 378); MP. frasp[plsp] (Mackenzie: 73); Prth. Prdwy, Khot. fsp' (Hasandoost: 592).

- Vrisatəm frasčimbananąm frasčimbaiiōiţ tarasča āpō nāuuaiiāa [Vd.18.74]

- He should set up thirty beams across the deep water (Skjaervo: 145).

gāo.stāna-: sb. mas. "cowpen, stable".

Av. ${ }^{5}$ gav- "cow" + stāna- "place" (Bartholomae: 1605); MP. gōstān [gwst'n] (Mackenzie: 79).

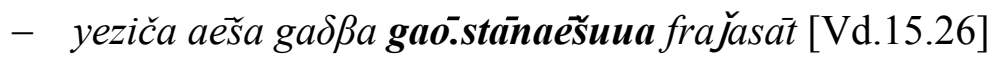

- If a bitch be near her time and be lying in an ox-stall ... (Darmesteter: 178)

gātu-: sb. mas.ntr. "Place".

Av. Derivation: āsitō.gātu- "sat in a place"

Skt.gātáv- (Bartholomae: 989); OP. gā७u- (Kent: 183); MP. gāh [g’s] (Mackenzie: 76); MPT., Prth. g'h[gāh](Boyce: 70); Paz., NP. gāh (Nyberg: 80).

- apąm ...yäpara ahmaț hištznta ... hamiia gatuuō [Yt.13.33]

- According to their will and interest, they destroy the enemies in the place of battle (Pourdavoud: 67).

gāuuaiiana-: sb. ntr. "cowpen, stable, cowshed".

Av. gav- "cow" + stāna- "place" (Bartholomae: 1605); MP. gōstān [gwst'n] (Mackenzie: 79).

- narąm aißi.xšōi খne ... gauuąm gāuuaiianəm [Vd. 2.25]

- The length of a race course on each of its four sides as a keep for cattle (Skjaervo: 124). 


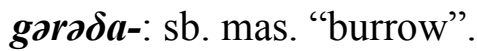

Derivated words in Av. gərəo $\underline{\text { o. }}$.kərəta- (Kellens: 892).

Skt.grha' - (Bartholomae: 522).

- yat ... paiti fraešstom bauuainti ayrō.mainiiauuanąm gərədąm [Vd.3.10]

- Wherever there are most dens, housing the creatures belonging to the Evil spirit (Skjaervo: 126)

han.kana-: sb. mas. "haven".

Av. han/ham+ kan- (Reichlt: 278); Skt. Khadā-, root: khan-/ khā (Mayrhofer: 445);

OI. *kan-a- (Mansoori: 222); IE. *Kha-n- . 'Kēn-, " ${ }^{*}{ }^{\mathrm{w}} \mathrm{el}$ (Pokorny: 1489); OP. kan- (Kent: 178);

MP. kandan(Mackenzie: 97); MPT. qn- (kan) (Boyce: 52); Prth. Kan (Gilain : 89); Sogd.kn- (kan)

(Gharib: 180); Paz. Xandan(Nyberg: 111).

- tąm yazata mairiiō tūiriiō frayrase han.kaine paiti aクhä zamō [Yt.5.41]

- To her offered up a sacrifice, the wicked Turanian Afrasyab, in his cave under the earth (Molayi: 74).

ištiia- ${ }^{1}$ : sb. ntr. "sun dried brick, brick".

Skt. iștikā- , iștakā- (Bartholomae: 378); MP. xišt [hšt ${ }_{+1}^{1]}$; Prth. hyštyg [hištīg](Mackenzie: 163) .

- auua hē gātūm baraiian ... ištiiehe vā zārštuuahe vā ... pasnūm [Vd.8.8]

- On that place they shall dig a grave, half a foot deep if the earth be hard, half a height of a man if it be soft, they shall cover the surface of it with dusts of bricks, of stones, or of dry earth (Darmesteter: 95).

$\boldsymbol{k a n}^{2}$ : vb. "to dig, to tear out".

Av. Present stem: kan- , kana- ,kānaiia- (Kellens: 14); inf: kantə̄e, ka ${ }^{\mathrm{n}}$ tanaiy; participle: kanta(Bartholomae: 473); OI. kan-a- ${ }^{*}$ (Mansoori: 222); Skt. khan-/khā (Mayrhofer: 445); IE. 'Kha-n- ، *Kēn- , "k ${ }^{\mathrm{w}} \mathrm{el}($ Pokorny: 1489); OP. kan- (Kent: 178); MP. kandan(Mackenzie: 97); MPT. qn- (kan) (Boyce: 52); Prth. Kan (Gilain : 89); Sogd.kn- (kan) (Gharib: 180); Paz. Xandan(Nyberg: 111).

- yaţ bā paiti fraēštzm daxma uzdaēza vikanti yahmiia [Vd.3.13]

- Wherever the most tombs are destroyed, in which dead men are laid down (Skjaervo: 126).

kayha $-^{3}$ : sb. mas. "brass".

Root in Av. Kan- (Bartholomae: 437); OI. "kanha- (Daryayi: 50); Skt.Kamsa- (Mayrhofer: 285);

OI. kan-a- ${ }^{*}$ (Mansoori: 222); Skt. khan-/khā (Mayrhofer: 445); IE. *Kha-n- ' ${ }^{*}$ Kēn- , "kw el(Pokorny: 1489); OP. kan- (Kent: 178); MP. kandan(Mackenzie: 97); MPT. qn- (kan) (Boyce: 52); Prth. Kan (Gilain : 89); Sogd. kn- (kan) (Gharib: 180); Paz. Xandan (Nyberg: 111).

- upa duuarəm xša Эrösukəm apano.təməm kayhaiia bərəzantaiia ašaunanaiia [Yt.5.54]

- By the castle khashathro-saoka, that stands high up on the lofty holy kangha (Darmesteter: 66)

Kar-: vb. "to build".

Av. Present stem: čar- , kərə- ,kərənu-; past stem: Kiriia-; inf: čartanaiy, kərətə̄e; participle: Kərəta(kellens: 14); OI. *kar- (Mansoori: 224); Skt. kr- (Mayrhofer: 311); IE. * ${ }^{\mathrm{w}}{ }^{\mathrm{w}} \mathrm{er}-$ (Pokorny: 1808); OP. kar- (Kent: 179); MP. kardan [ $\mathrm{krtn}^{1}$, klty , BYDWN-t $\left.{ }^{1}\right]$ (Mackenzie: 60); MPT. kyrdn [kirdan], Prth. kyrdn [kirdan] (Boyce: 88-89); Sogd. kwn- (Cheung: 237); Chrs. kir- (Hasandoost: 890); Paz. Kardan, NP. Kardan (Bartholomae: 444).

- àat tom varəm kəronauua [ Vd.2.25]

- So make that enclosure (Skjaervo: 124)

\footnotetext{
${ }^{1}$ In Old Persian aguru- means brick which has later get to new Persian.

${ }^{2}$ Kan-: to dig ; vi-kan-: to destroy; ni-kan-:to burry

${ }^{3}$ Most likely, this word also means a brass castle.
} 
kata-: sb.mas. "room, house".

Av. ${ }^{4}$ Participle :Kan- +ta; Skt. Khan- (Bartholomae: 432); OP. ka ${ }^{\mathrm{n}}$ ta- (Kent: 178); MP. kadag [ktk ${ }^{1}$ ] (Mackenzie: 95); MPT. \& Prth. kdg [kadag] (Boyce: 87); Paz. Kad(a) , NP. Kad(ah) (Nyberg: 116)

Derivation: katō.masah-"as big as a house" [Yt.8.36].

- ...nmāne nmāne ... Vräiiō kata uzdaiāiinąn aètahe yaț iristahe [Vd.5.10]

- In every house, in every village... for this one that is dead (Skjaervo: 140)

maē Эnana - : sb. ntr. "house, home, homeland".

Root Av. maēt- (Bartholomae: 1106); MP' . [myhn1] mēhan (Bartholomae: 1106), MP2. [mhm'nyh]mēhmānih (Mackenzie: 106); Prth. myhm'n[mēhmān] (Boyce: 98).

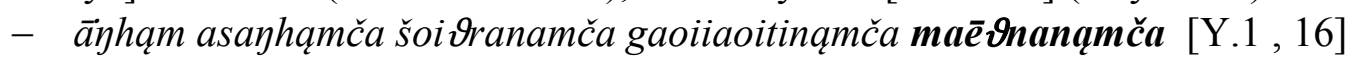

- To these places and settlements and grazing grounds and dwellings ... (Skjaervo: 6).

nəmāna-: sb. ntr. "house, home".

Derivation: nmānō.pati-"the chief of a house", nmāniia- "of a house ".

OI. 'dmāna > māna- (Mansoori: 239); Skt. mánah- ‘dámah- (Mayrhofer: 309); IE. *men "to stay”: (Pokorny: 2070); OP. man (Kent: 202); MP. mān[m'n'n ] (Mackenzie: 103);Prth. m'n[mān] (Boyce : 93); Sogd. myn `mnty- (mēnāmandē) (Gharib: 225); Paz. man, NP. Mān (Nyberg: 124).

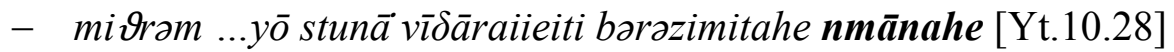

- Mithra... who arranges the columns of the high-pillared house (Gershevitch: 87).

pairi.daēza-: sb. mas. "enclosure".

Av. Pairi+ daēza- [daēz- + a (stem maker)] "heap, stack" (Bartholomae: 865); Skt. deha(Bartholomae: 674); MP. dēwār [dyw'l] (Mackenzie: 64).

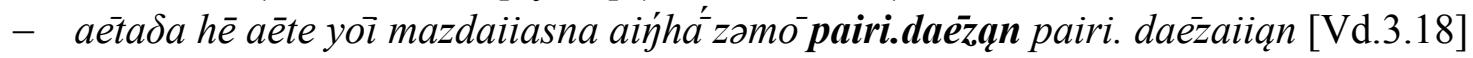

- Here on this earth these who sacrifice to Ahura Mazda should build enclosures for him (Skjaervo: 127)

panti-5: sb.mas. "path, road".

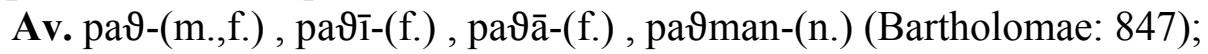

Skt.patháh- , pántháh- (Bartholomae: 847); OP. pa७i- (Kent: 195); MP. pand [pnd] (Mackenzie:

119); MPT.,Prth. Pand (Boyce: 126);Sogd. Pnt ,Bctr. Pandago, Khot. Pandā (Hasandoost: 606).

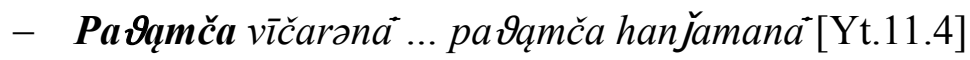

- At the branching-off of roads or a in the meeting together... (Darmesteter, Vol 2: 160)

pasu.vastra-: sb. ntr. "cowpen, stable".

Av. Pasu- "small cattle" + vastra- "somewhere to stay" [vah-"to stay"]; MP. pah ast [p'h st ${ }^{1}$ ] (Mackenzie: 79);

- ya ७a pasūm pasu.vastrom [Yt. 5.89]

- Just as a stable [keeps] the flock (Doostkhah: 313)

pərətu $^{6}$-: sb. mas. "passage, bridge".

Root in Av. Par- ; MP. puhl[pwhl] (Mackenzie: 61); Prth. pwrt (Hasandoost: 589); Paz. Puh(a)l, NP. pul(Nyberg: 162).

- hiiaţ aibīgəmən ya ७rā činuuatō pərətuš ... [Y.46.11]

- When they have reached the place of the account-keeper's bridge (Humbach: 171).

\footnotetext{
${ }^{4}$ Some think the root of this word is kat- " to hide" (Hasandoost: 582) and the others think of kan- "to dig" as the root (Bartholomae: 432). the second one sounds more logical to the authors.

${ }^{5}$ Apparently, the only definition of this word in Avestan is "path, road" but in middle Persian, in addition to the old meaning it also means "advice". However, later in New Persian, it almost loses the older definition.

${ }^{6}$ Also pašu-
} 
pouruša-: adj. "gray, white".

Av.paouruša-, Derivation: pourušaspa- "father of Zoroaster"; Skt. parusa- "stained" , palita"grey"(Hasandoost: 741); MP. pīr[pyl] pīr[pyl] (Mackenzie: 126).

- pourušō asti varsō [Vd.7.58]

- rickets and hair untimely white (Darmesteter: 88 )

rai Эiia-: sb. ntr. "path, road".

Skt.rathyā- (Bartholomae: 1508); OI.*rā७a- (Nyberg: 165);MP. rāh[1's](Mackenzie: 128);MPT.,Prth.[r'h]rāh (Hasandoost: 606); Paz., NP. rāh (Nyberg: 165).

- dāta xratə̄̌s hizuuō rai

- May the giver of intellect instruct (my intellect) with good thought to serve (my) tongue (as) charioteer of my prayer (Humbach: 184).

raočana-": sb. ntr. "window".

Av. Root: raok-derivation: satō.raočana-.(Reichelt: 247); Skt. raocaná- (Bartholomae: 1489); MP. rōzan [lwcn $\left.{ }^{1}\right]$, rōz(b)ānag[lwc(p)'nk $\left.{ }^{1}\right]$ (Mackenzie: 131).

- nmänəm... sato.raočanom ... hazayrö.stunəm [Yt.5.101]

- A house... a hundred-opening ... a thousand-column.

raodita- ${ }^{8}$ : adj. "red".

Skt. róhita- (Bartholomae: 1495); Chrs. Rxt ,Khot. Rusta (Hasandoost: 751).

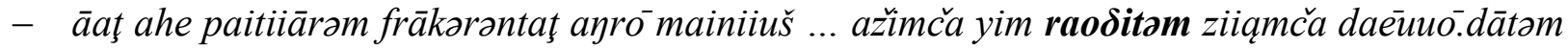
[Vd.1.2]

- Then the evil Spirit full of destruction whittled forth as its antagonist, a dragon, the red, and the winter made by the old gods (Skjaervo: 120).

ši ${ }^{9}$-: vb. "to habit".

Av. Present stem: ši-, šaē- (Kellens: 69); past stem: ši-, šaē-; participle: šita; inf. šit̄e, šiti(Bartholomae: 1706); Derivations: šōi७ra- "dwelling", gava.šaiiana- "cattles stable", airiiiō.šaiiana"iranian houses", hu.šaiiana-"someone who has a good dwelling”.Skt. ksay- (Cheung: 371); IE. "tḱei- (Pokorny: 626); Ltn. Situs- (Bartholomae: 1706).

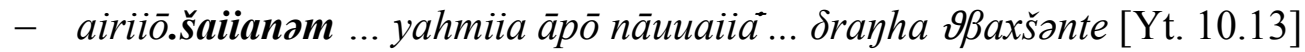

- From there the mightiest surveys the whole land inhabited by Iranians (Gershevitch: 79).

scind ${ }^{10}-:$ vb. "to destroy".

Av. Present stem: sčandaiia-, sčəndaiia-sčindaiia- (Bartholomae: 1586); Derivation: skənda"destruction" (Reichelt: 269); Skt. skándha- "branch"(Reichelt: 269); MP. škastan [TBLWN-tn"] (Mackenzie: 142); MPT. 'škn- [iškenn-] (Hasandoost: 871,873); Paz. Škastan, škandan, NP. Šikastan (Nyberg: 188).

- yō rasmanō scìndaiieiti ... auui rasmanō scìndaiieiti [ Yt.14.62]

- Angry, annoyed, [he] destroys the house and ... (Pourdavoud: 430)

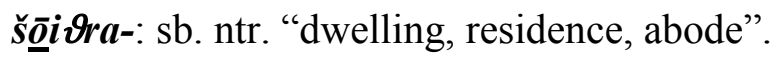

Avv. Root: ši- , derivations: šōi rōstāg [lwtst'k] (Mackenzie: 131); Prth. rwdyst'g[rōdestāg] (Boyce: 129); Paz. , NP. rōstā(Nyberg: 171).

- yazāi šōi Qrahe baxtāram tištrīm... [Yt.8.1]

- The moon, lodging and sacrificial food we worship... (Panaino: 27)

\footnotetext{
${ }^{7}$ Also raočina-

${ }^{8}$ The avestan synonym for this word is suxra- which has come to the new Persian unlike this word.

${ }^{9}$ also $x s ̌ i-$.

${ }^{10}$ Also sčand- and skand- (Cheung: 342 )
} 
spaēta- ${ }^{11}$ : adj. "white, whitish".

Av.: spaēitia-, spita-; Skt.śvetá- (Mayrhofer: 679); IE. "kûuei-to -(Pokorny: 1776); MP. spēt[spyt1](Mackenzie: 136); MPT., Prth.'spyd [ispēd] (Boyce: 40); Sogd.'sp'ytch, 'sp'yt'k, sp'yt, Khot. sśita- (Hasandoost: 749); Paz. Spēdī (Nyberg: 178).

- Spanəm ... spitam zairi.gaošəm [Vd.8.16]

- When either the yellow dog with 4 eyes, Or the white dog with yellow ears, is brought there... (Darmesteter: 97).

sruua-: sb. ntr. "lead".

Mp. srub [sl(w)p] (Mackenzie: 136);NP. Sorb.

- ayayhaēnəm vā srum vā nitəma x̌̌a Vra vairiia [Vd.16.6]

- In vessels of brass, or of lead, or of any common metal (Darmesteter: 182).

storoma-: sb. mas. "store room".

Av. Root: star- ; Skt. Root: strnắti- ‘strnóti-- ‘stárate g strtah- (Bartholomae: 1596); MP. Wistardan [wstl-tn $\left.{ }^{1}\right]($ Mackenzie: 160).

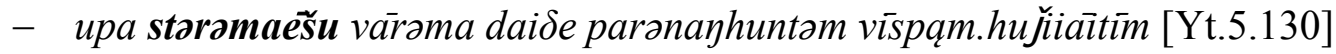

- and in its store whatever one wishes ...(Mowlaee: 145)

stǔna-: sb. mas. "beam".

Av. Derivation: hazanrō.stǔna- (Reichelt: 277); Skt. sthǔnā-; MP. $\operatorname{stūn}(\mathrm{ag})\left[\operatorname{stwn}(\mathrm{k})^{1}\right]($ Mackenzie: 139); MPT. , Prth. 'stwn[istūn] (Boyce: 41); Paz. stūn, NP. sutūn (Nyberg: 181).

- mi Vram yōstunä vídäraiieiti barazimitahe nmānahe [Yt.10.28]

- Miýra... who arranges the columns of the high-pillared house (Gershevitch: 87).

suxra-: adj. "red".

Av. Root: soak- (Bartholomae: 1582); Skt. śukrá- "bright" (Hasandoost: 746); MP. suxr [swhl] (Mackenzie: 140); MPT. swhr[suhr], Prth. swxrg[suxrag] (Boyce: 135).

- ā Vrąmča suxrąm saočintąm [Vd.2.8]

- red and blazing fires (Skjaervo: 122)

siī̄uua-" ${ }^{12}$ adj. "black".

Skt. śyāvá- (Mayrhofer: 661); MP. syā (Mackenzie: 140); MPT. sy`w (syāw) (Boyce: 83); Sogd. š w (šāw) < syāva- (Gharib: 370); Chrs. š’wš (Hasandoost: 751); Paz. Syāh, NP. Syāh (Nyberg: 176).

- aspahe kahrpa siiamahe [Yt.8.21]

- in the shape of a black horse ... (Panaino: 47)

tutūk-: sb. fem. "mud, clay".

Skt. tvak- .

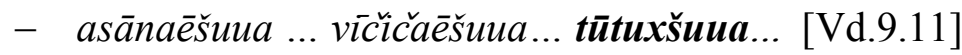

- Thou shalt place stones as steps to the holes; or potsherds, or stumps, or clods, or any hard matter (Darmesteter: 122).

usa- : sb. mas. "well".

Skt. útsa-"stream",udán-“water" (Hasandoost: 596).

\footnotetext{
${ }^{11}$ Synonyms: auruša-, auruška-

12 sāma-
} 
uz.dā̄za ${ }^{13}$-: sb. mas. "wall".

Av. Uz + daēza- [daēz- + a (stem maker)] "heap, stack" (Bartholomae: 411); Skt. deha(Bartholomae: 674); MP. dēwār [dyw'l] (Mackenzie: 64).

- yōaètam uz.daēzom uzdista [Vd.15.36]

- He who erected the wall ... (Darmesteter: 178)

var-: sb. "castle".

Av. Root: var- "to cover" (Bartholomae: 1596); Skt. Vara- (Mayrhofer: 524); OI. " war- (Mansoori: 434); IE. "uner- "to protect" - (Pokorny: 3363); OP. var- (Kent: 206); MP. war (Mackenzie: 153); Paz. var (Nyberg: 203).

- āat tam varəm kərənauua [ Vd.2.25]

- So make that enclosure (Skjaervo: 124)

vǐs ${ }^{14}$-: sb. fem. "house, home, homeland, village".

Av. Root: vis- "to serve" (Bartholomae: 1314), Derivations: viso.baxta "rural" , viso.iric- , vispaiti- "The village chief", vis.hauruua- "The village guard", vis.harezena-, euuisa"homeless"(Kellens: 365-366).

Skt. "viś- , root: veś- (Mayrhofer: 584); IE. "ųeiḱ- "to habit" - (Pokorny: 3264); OP. viө- (Kent: 208); MP. vis (Mackenzie: 159); MPT. wys [wis] (Boyce: 97).

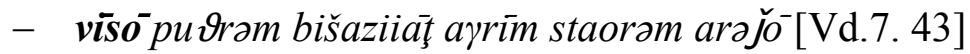

- He shall heal the son of a town(-master) (Skjaervo: 138)

$\boldsymbol{x a n}^{-15}$ : sb. fem. "well"

Av. Root: kan- (Bartholomae: 583) or xā- (Hasandoost: 596) or * xa- (Cheung: 440).

Skt. khá-(Mayrhofer: 442); Sogd. $\gamma \gamma$ h (xāx) (Gharib: 161); MP. Xān (Mackenzie: 106); MPT. x'nyg (xānīg) (Boyce: 99).

- apamčā $\boldsymbol{x} \overline{\boldsymbol{a}}$ yazamaide [Vd.21.7]

- we worship the water and well.

$\boldsymbol{x} \check{\boldsymbol{s}} \boldsymbol{i}-\mathrm{:}$ vb. "to habit".

Av. Present stem: xši-, xšaē- (Kellens: 69); participle: xšita; inf. xšitว̄e, xšiti- (Bartholomae: 1706); Derivations: $x \check{s} a$ Өra- "town".

Skt. ksay- (Cheung: 371); IE. * tḱei- (Pokorny: 626); Ltn. Situs- (Bartholomae: 1706).

yauuan- ${ }^{16}$ : sb. ntr. "Storeroom"

Av. from: yauua- "corn, grains"; Skt. yáva-;(Bartholomae: 1266).

- spiš ...yim ...yaom yauū̄ huua nižgajhanti [Vd.17.3]

- Which gobble up the barley in the barley bins... (Skjaervo: 140).

zairita- : adj. "yellow".

Other forms in Av. zari-, zāri- (Reichelt: 279); Skt. hárita- (Bartholomae: 1681); MP. zart[zlt] (Mackenzie: 169); Sogd. Zyrtyh (Hasandoost: 742).

- Spanəm ... spitəm zairi.gaošəm [Vd.8.16]

- When either the yellow dog with 4 eyes, Or the white dog with yellow ears, is brought there... (Darmesteter: 97).

\footnotetext{
${ }^{13}$ Also uzdazay-

${ }^{14}$ Also vi $\vartheta$

${ }^{15}$ also $x \bar{a}$ -

${ }^{16}$ Also yaon-
} 
ฯanj-v. "to draw".

$\mathbf{M P}^{17}$.infinitive: saxtan [s'htn ${ }^{1}$ ], Present stem: sanj- (Mackenzie: 134); Prth. 'hynj- (Cheung: 391);

Khot. thamy̆- (Hasandoost: 896); NP. sanǰ̀idan.

- yahmāi ... auruuanta yuxta vāša ७anǰasänte [Yt.10.136]

- For whom white courses, yoked to his one-wheeled, golden chariot which is all-glittering with (precious) stones... (Gershevitch: 142-143)

\section{CONCLUSION}

Few people have ever analyzed and interpreted the ancient Persian texts which are mostly religious in the context of architecture and art. The customary way to study the ancient art and architecture is to analyze the remaining buildings.

Avesta is a very valuable book which gives us some unique information about different fields and can be analyzed from different angles.

Iranian architecture is an art which has been affected by many factors including religion, in its long life. Therefore, Avestan Architecture is an image of the architecture illustrated in Avestan documents, in which the constant quarrel between God (Ahuramazda) and Devil (Ahriman) can be still traced.

In this research, an etymological-descriptive lexicon, collocated by the English Alphabet, was collected from Avestan vocabularies which are related to architecture.

The most important question that the authors had in mind from the beginning was whether there is a difference between the modern definition and concept of architecture and the ancient one.

Once you study the Avestan architecture and compare it with the earlier concepts of architecture you had had figured, you can certainly claim that they are obviously different. This difference is about the different understandings of people from architecture, variety of architectural spaces, and the change in the position of architecture in people's life, from a mere dwelling to an art-science.

In Avesta, the qualities of a described place are directly related to its owner. Therefore, Devilish spaces are described as horrifying and dark places and the divine spaces are extensive, radiant and full of columns and windows.

At the end, the authors assume that more interdisciplinary researches could be done in architecture and archaeology and especially in accordance of ancient texts and architecture.

\section{References}

[1] Amoozegar. J. (1995). Tarikh-e-e-Asâtīrī-ē- Iran [Mythical history of Iran]. Tehran: Samt.

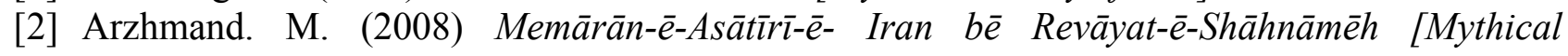
Architects of Iran narrated by Shahnameh]. Soffeh. NO.16, pp. 5-47.

[3] Bahar. M. (1983). Az Ostūrē tā Tārīkh [From Myth to History]. Tehran: Cheshmeh.

[4] Bartholomae, Chr. (1961).Altiranisches Wörterbuch (first pub.1904). Berlin: Waiter Deguyter Gruyter \& Co.

[5] Boyce, M. (1977). A Word-list of Manichean Persian and Parthian. Leiden: Brill.

[6] Cheung, J. (2007).Etymological Dictionary of the Iranian Verb. Leiden-Boston: brill.

[7] Darmesteter, J. (1880-1883). Zend Avesta. Vol.1- 2. London: Oxford University. At the Clarendon Press.

[8] Doostkhah.J. (1992). Avesta. Tehran: Morvarid.

[9] Gershevitch, I. (1967). The Avestan Hymn to Mithra: Cambridge University Press. Cambridge. [10] Gharib .B. (2004). Farhang-ē-soghdi [Soghdi Farhang]. Tehran: Farhangan.

[11] Gilain, A. (1966). Essai sur la Langue Parthe. Louvain: Institut Orientaliste, Université de Louvain.

[12] Godard. A. (1979). The Art of Iran. Habibi. B. Tehran: Melli University.

\footnotetext{
${ }^{17}$ In middle Persian this verb only means "to measure, to evaluate".
} 
[13]Hasandoost.M. (2004).Farhang-ē-rishē shenakhti-ē-zabān-ē-Fārsi [Etymological Dictionary of Persian Language]. Tehran: Zaban va Adab - e- Farsi va Asar.

[14]Horn, P. (1974). Grundriss der Neupersischen Etymologie (first pub.1893). New York: Hildesheim.

[15]Humbach, H. (1961) "Bestattungsformen im videvadat", zeitschrift fur vergleichende sprach forchung 77, pp. 99-105.

[16].... (1991). The Gathas of Zarathushtra: Heidelberg: Carl Winter Universitat.

[17].... (1998). Zamyād Yasht. Wiesbaden: Harrassowitz.

[18]Jackson, A.A.W. (1892).An Avesta Grammar in Comparison with Sanskrit. Stuttgart: Wkohlhammer.

[19] Jafari Dehaghi. M. (2011). “Ārmānshahr-ē- hakīm-ē- Tūs dar Shāhnāmeh" [The Utopia of the sage of Tūs in Shāhnaeh]. Pazhoohesh ha ye Iran shenasi [Iranological Research], PP. 1-8.

[20]Kellens, J. (1990). Les Textes Vieil-Avestiques. Vol 11. Wiesbaden: Dr. Ludwig Reichert

[21] .... (1995). Liste du Verbe Avestique. Wiesbaden: Dr. Ludwig Reichert.

[22]Kent, R. G. (1953). Old Persian. New Haven: American Oriental Society.

[23] MacKenzie, D. N. (1971). A Concise Pahlavi Dictionary. London: Oxford University Press.

[24] Malandra, W. (1983) An Introduction to Iranian Ancient Religion. Minneapolis: Minnesota Press.

[25]Mayrhofer, M. (1964-1992-1996). Etymologisches Wörterbuch des Altindoarischen. Heidelberg: Carlwinter.

[26] Mansoori.Y. (2005). Barrasī-ē-rīshē shenākhtī-ē-fêlhāyēe-zabān-ē- Fārsi [Etymological Survey of the Verbs of Pahlavi Language]. Tehran: Farhangestan-ē- Zabān va adab-ē-Fārsi va āsār.

[27] Mowlaee, C. (2013). Aban Yasht. Tehran: Center for the Great Islamic Encyclopedia.

[28]Nyberg, H. S. (1964-1974).A manual Of Pahlavi,Part I:Texts;Part II:Glossary. Wiesbaden: Harrassowitz.

[29]Panaino, A. (1990). Tištriya. The Avestan Hymn to Sirius. Roma: Instituto Italiano per il Medio ed Estremo Oriente.

[30]Pirniya. M.K. (2005) sabk shenāsi-ē- memāri-ē-irani [the stylistics of Iranian architecture]. Tehran: Soroush- e- Danesh.

[31] Pokorny, J. (2007). Proto-Indo-European Etymological Dictionary: Indogermanisches Etymologisches Wörterbuch. [http://dnghu.org].

[32] PoorDavoud. E. (1968). Yashtha [the Yashts]. Vol 1 and 2. Tehran: Asatir.

[33] .... (2008). Yasna. Tehran: Sokhan.

[34] Pope,A.U. (1969).A Survey Of Persian Art, Vol.2.3.8. Oxford: Oxford University Press.

[35] Razi.H. (1979). Vandidād. Tehran: Vahdat.

[36] Reichelt, H. (1911). Avesta Reader: Texts, Notes, Glossary and index. Berlin: Photomechanischer Nachdruck Walter De Gruyter \& CO.

[37] .... (1967).Awestisches Elementarbuch (first pub.1909). Heidelberg: Wissenschaftliche Buchgesellschaft

[38] Skjaervo, P.O. (2006). Zoroastrian Texts. Cambridge: Harvard University

[39] Tafazzoli. A. (1997). Tārikh-ē-Adabiyāt-e-eIran- $\bar{e}$ Pīsh az Eslam [History of Literature of Pre-Islamic Iran]. Tehran: Sokhan.

[40] Zarei. M. E. (2000). Ashnāȳ̄ bā Memārī-ē- Jahān [Getting to Know the World's Architecture]. Hamedan: Fan Avaran. 